\title{
THE OVERALL EFFECT OF OBSERVATIONS ON THE SOCIAL INTERACTIONS OF VICTIMS OF THE MALUKU CONFLICT
}

\author{
Harling Jermias Hartes Van*, Sapulette Alce Albartin \\ State Christian Institute of Ambon, Indonesia \\ *E-mail: mesutmustaqim23@gmail.com
}

\begin{abstract}
The Maluku conflict in 1999 impacted the social life of the Maluku people and reduced cultural awareness so that the cohesion of the multi-religious and multi-ethnic community was getting weaker. Social boundaries are penetrated by differentiation, leading to the weakening of psychological aspects; several practical experiences become revenge because memories are formed in conflict zones filled with threats, anarchic actions, intimidation, terror, and murder. This study aimed to analyze the effect of the overall experience on the social interaction of victims of the Maluku conflict. This study uses a qualitative method with a phenomenological approach. These results indicate that the greater the bad experience (uncomfort) and the pleasant experience (comfort), the more rigid the social interaction. Most researchers say that the causes of conflict are related to each other systematically, and therefore the problem must be viewed holistically. Based on the principles of psychoanalysis, three factors were found that influenced the social interaction of victims of the Maluku conflict. Biological factors, psychological factors, and sociological factors. Biologically, in a society in conflict, social interaction occurs in stable, specific segregation whose inhabitants have fraternal relationships, such as social interactions between parents and children, siblings, relatives, and family. This is due to having a brotherly relationship (blood) in which a sense of mutual trust has been created for one another. Psychologically, the victims of the Maluku conflict had several subjectively constructed experiences. This experience can be a pleasant experience or an unpleasant experience.
\end{abstract}

\section{KEY WORDS}

Phenomenal field, social interaction, victim, Maluku conflict.

The history of the life of the Indonesian people, changes, and continuity continues. Indonesia's history is filled with the ups and downs of various political systems. The Republic of Indonesia, as a political system, was built on the ruins of the Japanese political system, which had destroyed the previous political system, namely the Dutch political system. The Dutch political system has also collapsed, sooner or later - various political systems spread across the archipelago. After the fall of President Soeharto, there were many horizontal and vertical conflicts in Indonesia. One of them, which is classified as a prolonged conflict, is the conflict in Maluku. Maluku is an area with a very high level of conflict vulnerability and lasts for a long time.

Maluku society is a society with high ethnic and religious heterogeneity. Not only natives of Maluku, migrants from various parts of Indonesia, especially Bugis, Buton, Makassar, Minahasa, Javanese, and Chinese, also inhabit this area. In terms of religion, Islam and Christianity are the religions of most of the population of Maluku, followed by Catholicism, Hinduism, and Buddhism. Previously, they lived in harmony side by side. However, this changed when early 1999, which day coincided with Eid al-Fitr, Maluku turned into a communal and bloody conflict field. The conflicts that have occurred in Maluku until now still often lead to riots that result in destruction. This shows the same tendency that the existing and implemented resolutions cannot extinguish the problems that occur at the grassroots level of the problem. Rumors spread that the 1999 conflict was a SARA-related conflict because there was no respect for human life and between religious people with one another. Conflicts are also accompanied by symbols that symbolize the different identities of the conflicting groups. The impression is that religious people have been trapped in detecting relationships with negative prejudices, suspicions, and fears to no longer establish peaceful 
and harmonious relations. The conflict impacts mental health and economic conditions far beyond the area where the actual violent incident occurred (Fusiah, 2020). People experience pressure because conflict is driven by self-interest in order to avoid disappointment. People are disappointed because they do not believe in the group that is their opponent. The condition of the community is increasingly depressed because of the clear communicative role and segregation of the settlements. Individuals can finally decide suspicious actions in relationships with conflicting opponents (Nurhadi, 2004). This whole experience is called the phenomenal field. The phenomenal field is a frame of reference from an individual that others cannot know. If it is known to others except through empathic inference and henceforth, it can never be known perfectly. The phenomenal field is not synonymous with the field of consciousness. Consciousness is a symbol of experience. Experience includes everything that the organism can potentially experience and is present in the organism's consciousness at all times. Conscious experiences and unconscious experiences (Hall S. Calvin \& Linndzey Gardner. 2015) Victims of the 1999 conflict had experiences symbolized, among others, boundaries between groups, residential buildings, markets, shop houses, means of transportation, and houses of worship that were burned. The symbol of the cross, red, white, words like, acang and obet, Allahuakbar, and Laskar Kristen are symbols to distinguish the identities of opposing groups.

Meanwhile, experiences that are not symbolized are ignored. This study intends to analyze the phenomenal terrain of the 1999 conflict victims by finding the experiences experienced by conflict victims, both symbolized and unsymbolized. The focus of this paper is to find the linear effect of the phenomenal field.

\section{METHODS OF RESEARCH}

This study uses a qualitative method with a phenomenological approach. Qualitative methods seek to understand and interpret the meaning of an event of human behavior interaction in certain situations according to the researcher's perspective. Research that uses qualitative research aims to understand the object under study in depth. This research was conducted in Ambon, Maluku. The data collection techniques used were observation, interviews, snowball sampling technique, and documentation study. The validity of the data was carried out using triangulation techniques from sources, methods, investigators, and theories (Denzin, 2011). Data analysis techniques are data collection, data analysis, data reduction, data presentation, and concluding (Creswell. 2010).

\section{RESULTS AND DISCUSSION}

From the artistic side, social conflicts can manifest in three levels, namely conflicts at the level of values, conflicts at the level of norms, and conflicts at the physical level. Social conflicts at the value level involve disputes originating from differences in essential criteria that distinguish between good or bad, important or unimportant, valuable or not valuable. Conflict at the level of norms is a dispute that stems from differences regarding standards or rules of behavior, ranging from differences in habits to legal rules that give birth to harsh sanctions for violators. Meanwhile, conflict at the physical level is a conflict that manifests itself in and originates from differences in physical symbols and actual behavior. This can be found starting from the way of dress, the model of buildings and religious rituals, and open war and suicides that destroy not only the warring parties but also other parties that have nothing to do with it.

Social conflict refers to a form of social interaction between two or more people/groups, in which each party tries to defeat the other or even eliminate the other party. As a form of social interaction between various individuals and groups, social conflict is one of the natural essences of social interaction. Social conflict cannot be eliminated; what can be done is an effort to manage and maintain conflict at a level that does not destroy the imagined and desired togetherness. In Ambon, several ethnic groups mingle in their social interactions, including ethnic Bugis, Buton, Javanese, Toraja, Padang. Communication that occurs between groups of people or ethnic groups characterized by the same language and origin. 
Biologically, social interactions occur in a stable manner, certain segregations whose residents have kinship relations, such as social interactions between parents and children, siblings, relatives, and family. This is due to having a brotherly relationship (blood) in which a sense of mutual trust has been created for one another.

Meanwhile, outside of segregation that does not have a brotherly relationship, social interactions tend to be pseudo-real because they do not have a brotherly relationship in which mutual trust is established. This subjective construct of thought biologically dwarfs the level of social interaction in society (Rosana, 2015, 217). Difference itself is an inseparable part of the reality of life. These differences include physical characteristics, intelligence, knowledge, customs, or beliefs. Differences can be a potential problem. Bias differences that cannot lead to reciprocal relationships that are carried out can change, influence, improve between one individual and another, and interstimulus and response between individuals and groups.

The understanding conflict between groups is not simple. Many factors cause conflict between groups. Conflicts can arise due to economic, psychological problems (jealousy, prejudice), law, economy, and differences in-group identity (ethnicity, religion). Conflicts between groups (intergroup) can also occur due to political, religious, ethnic, historical, and economic problems. Costarelli (2012) holds that the relationship between groups should be seen from the group's perspective, not the individual. Each individual in society is grouped according to different categories, such as gender, ethnicity, religion, and occupation. Thus, individual identities are formed, which can later form group identities. Each group feels superior to the other groups. The group becomes the center of everything (ethnocentric) and tends to be in-group and sees other groups as enemies.

Things like this have the potential to cause intergroup conflicts. Psychologically, the victims of the Maluku conflict, 1999, had several subjectively constructed experiences. This experience can be a pleasant experience or an unpleasant experience. This accumulation of experience in Rogers' concept of thought is called the phenomenal field. The phenomenal field is the overall experience experienced by every organism with conscious or unconscious properties depending on whether the experience underlies the phenomenal field is symbolized. While consciousness is part of the symbolism of experience and the organism (humans) can distinguish these two types of symbols through subscription. Subception is the mechanism that distinguishes different individual experiences from self-concept. Depending on the threat level in an experience, they may maintain their self-concept by denying the experience or distorting its perception (Calvin \& Linndzey Gardner 2015).

Experience is related to consciousness. Awareness does contain not only elements of understanding but also affective aspects (feelings) and effective-active aspects (implementation) (Bakker, 2000). Therefore, humans tend to examine the experience symbolized by the world as it is to act realistically. Violence may have increased the likelihood of mental health problems (Hildebrand, 2019).

The roots of violence and protracted social conflict in North Maluku are caused by geographical, demographic, cultural, and political factors - and are influenced by internal factors (conflicts between elites) in the struggle for hegemony, natural resources, and power. The conflict resolution process is a series of activities of various parties involved on an ongoing basis through conflict prevention and management. Therefore, conflict resolution addresses the causes of conflict and seeks to build new and long-lasting relationships between hostile groups. Conflict transformation is an effort to overcome the sources of broader social and political conflicts and to transform hostile forces into positive social and political forces. Sociologically, the 1999 Maluku conflict victims had an irregular pattern of interaction, the interaction built after the Maluku conflict was an interaction pattern based on segregation. This means that social interaction is stable in a locus or region (segregation) whose residents generally have the same ethnicity, religious ethics, etc.

While outside of this segregation, the interaction pattern is pseudo, meaning that social interactions carried out by fellow communities or victims of the Maluku conflict are carried out solely to prevent social friction that will trigger conflict. The social interactions that usually occur after the Maluku conflict can only be seen in the context of the hierarchy of needs at meeting the needs of life. This means that the construct of subjective thought from the 
phenomenal field has become self-limiting. Social interactions in society can function in an orderly, orderly, and regular manner if people can act following their social context and the ability to objectively assess their behavior from the point of view of others (Narwoko \& Suyanto, 2007). Mistakes in forming the subjective construct of a phenomenal field will lead to conflict because conflict tends to occur in social relationships. After all, a person or several people can always use violent cooperation in an interaction setting (Ritzer \& Goodman, 2017).

One source of conflict is a difference, but differences can be used as a binding force and self-protection if these differences can be adequately managed. Repeated violence resulted in a significant increase in post-traumatic stress disorder and severe stress in communities previously affected by mass conflict. The occurrence of a process of social interaction that results in a social change cannot be separated from the existence of social interaction activities which are one of the scopes of Sociology of Communication. Comprehensively, the Sociology of Communication discusses social interaction with all aspects related to the interaction process, how the interaction (communication) is carried out, using what media, how the effects of the media are, how social changes in a society driven by the media develop, and what kinds of social consequences are borne by the community as a result of the changes that occur.

\section{CONCLUSION}

Based on the principles of psychoanalysis, three factors were found that influenced the social interaction of victims of the Maluku conflict. Biological factors, psychological factors, and sociological factors.

\section{REFERENCES}

1. Baker, K. C., \& Aureli, F. (2000). Coping with conflict during initial encounters in chimpanzees. Ethology, 106(6), 527-541.

2. Costarelli, S., \& Sanitioso, R. B. (2012). Ingroup ambivalence and experienced discomfort: The moderating roles of affective versus cognitive attitudinal basis, group identification, as mediated by negative beliefs about the ingroup. The Journal of social psychology, 152(2), 158-173.

3. Creswell, John W. "Mapping the developing landscape of mixed methods research." SAGE handbook of mixed methods in social \& behavioral research 2 (2010): 45-68.

4. Denzin, N. K. (2012). Triangulation 2.0. Journal of mixed methods research, 6(2), 80-88.

5. Fausiah, F., Turnip, S. S., \& Hauff, E. (2020). Gender differences and the correlates of violent behaviors among high school students in a post-conflict area in Indonesia. Asia-Pacific Psychiatry, 12(3), e12383.

6. Gustira, M. A., Nurhadi, Z. F., \& Suseno, N. S. (2016). Pemberitaan Konflik Perdana Menteri Australia Tony Abbot. Jurnal Komunikasi Universitas Garut: Hasil Pemikiran dan Penelitian, 2(1), 47-56.

7. Hildebrand, DL (2011). Demokrasi pragmatis: Penyelidikan, objektivitas, dan pengalaman. Metafilsafat , 42 (5), 589-604.

8. Hall, C. S., Lindzey, G., \& Campbell, J. B. (1957). Theories of personality (No. 04; BF698, H3.). New York: Wiley.

9. Livne, M., Rieger, J., Aydin, O. U., Taha, A. A., Akay, E. M., Kossen, T., ... \& Madai, V. I. (2019). A U-Net deep learning framework for high performance vessel segmentation in patients with cerebrovascular disease. Frontiers in neuroscience, 13, 97.

10. Ritzer, G., \& Stepnisky, J. (2017). Modern sociological theory. Sage publications.

11. Suyanto, J. D. N. B., \& Narwoko, J. D. (2007). Sosiologi teks pengantar \& terapan. Jakarta: Kencana, cet, 3.

12. Rosana, E. (2015). Konflik pada kehidupan masyarakat (Telaah mengenai teori dan penyelesaian konflik pada masyarakat modern). Al-Adyan: Jurnal Studi Lintas Agama, 10(2), 216-230. 